\title{
Compentency of Elementary School Teacher In Written Language Learning
}

\author{
E Sukma ${ }^{1}$, M S Lena ${ }^{2}$, Eahmatina $^{3}$, A Suriani ${ }^{4}$, M Habibi $^{5}$ \\ \{elfiasukma@fip.unp.ac.id\} \\ 1,2,3,4,5 Universitas Negeri Padang, Jl. Prof Dr. Hamka Air Tawar, Padang, Indonesia
}

\begin{abstract}
Learning written language in primary school is still low. This problem influence by teacher ability in written language learning. This study employed mixed method both quantitative and qualitative approaches. Semistructure interview was conducted in data gathering. Furthermore, the data were analyzed using qualitative analysis. The subjects of this study were six elementary school teachers, six elementary school supervisors, and six lecturers. Quantitative data was obtained through a questionnaire filled by 303 elementary school teachers at grade 4,5 and 6 in Padang, West Sumatra Province. The data were analyzed using quantitative descriptive analysis with Statistical Package for Social Science (SPSS) software. This study constructed a competency framework required to be mastered by teachers in written language learning in Indonesian subject in elementary school, namely competency of cognitive, affective and psychomotor aspects.
\end{abstract}

Keyword : Elementary, Quantitative, School.

\section{Introduction}

Language is used in various fields such as economics, law, politics, and education. In education, especially language education, the utilization of language is packaged in four language skills, namely listening, speaking, reading and writing. These four language skills serve as basis of language learning from elementary level up to university. Every learner is empowered to master these four skills. Therefore, instructors strive to improve the successfulness of language learning through the achievement of four language competencies, i.e. listening, speaking, reading and writing.

Written language ability of Indonesian students was approximately 50\%. Analyzing of student learning outcome in reading literacy through the International Study (PIRLS) in 2011 found that students reading comprehension was still. Literature states that reading is not a popular activity among students[1]. Reading is important in everyday life and problems would be occur if students do not have the reading skill, therefore reading is needed.

Furthermore, reading is a basic language skill needed for academic and social life[2] [3]. It is the key to success and builds on the knowledge that allows individuals to be superior, better educated, and more intelligent[4]. Reading skill is foundation for success and contribute significantly to the improvement of cognitive skill, intellectual development, job success, career development, and the ability to respond to change[5]. Conversely, those who fail to 
acquire adequate reading skill likely face some problems such as dropping out of school, unemployment, and low overall income[6].

Furthermore, students also have problem in writing. Research showed that students' learning outcomes to write rhymes are still low[7]. Other problems are difficulty in developing topic of essay and word choice. Also, students found difficulty in develop an idea and needed a long times to finish their writing[8]. Writing skill is very important in language teaching in terms of ensuring proper communication for individuals to express himself, his thoughts and feelings accurately and clearly to the reader[9]. This skill is one of the goals of education that can be used in different social situations to show the complex intellectual activity because it is used as a means of formal communication[10, 11][12].

There is still a lack of the ability of teachers in learning written language in school that can be seen from Teacher Competency Test nationally with an average of 42.7 (Kementerian Pendidikan Nasional, 2012) and Teacher Competency Test in 2015 was 44.5 and it was below the standard value of 75. It seems the competency of teachers in learning written language needs to be improved. Teachers who are competent in written language learning can make the learning process favored by students. Creative teachers can develop cognitive, affective, and psychomotor aspect proportionally. Therefore, the development of teacher competence in written language learning needs to be improved so that the learning objectives can be achieved. This article aimed to describe the competencies required to be mastered by teacher in written language learning.

\section{Method}

This study employed a mixed approach that aimed to get the results of a comprehensive study. According to experts this research method was the approach taken by combining qualitative and quantitative approaches[13]. The method used was a method of sequential exploratory design. For qualitative approach, the data obtained through semi structure interviews. Interviews involved 18 respondents, consisting of six teachers, six elementary school supervisors, and six lecturers. For a quantitative approach, the data obtained from the questioner filled out by 303 teachers from grade 4,5 and 6 in Padang, West Sumatra Province, Indonesia. Questioner was constructed based on the results of the qualitative interviews that was used to identify the competencies that must be mastered by the teachers in Indonesian Language Subject. Questioner was analyzed using quantitative descriptive analysis with the software Statistical Package for Social Science (SPSS).

\section{Result and Discussion}

Here are described the results of an analysis of the data obtained based on interviews with 18 respondents. Based on the results of interviews showed that the necessary competence mastered by the teacher views on three aspects, namely cognitive, affective, and psychomotor. From the aspect of cognitive competencies teachers need to be mastered language skills theory that consisted of two sub-constructs, namely the nature of reading and writing; language skills learning method; language skills learning assessment; and reading skill. From the affective aspect, the competencies should be mastered by teacher seriousness and motivation in learning language skills. Furthermore, from psychomotor aspect, competencies should be mastered by 
teacher were writing skills, media utilizing skill, and implementing language skills learning skill.

Competencies aspects required to be mastered by teachers based on quantitative data analysis namely cognitive, affective, and psychomotor aspects. The result of the regression analysis showed that all indicators in cognitive, affective, and psychomotor aspects contribute significantly to the written language learning competencies. Further, dominant aspect in this study was the cognitive aspect by contributing 89.7 per cent. Then psychomotor aspects with a contribution of 75.2 per cent. Finally, aspects of which at least contributed was affective aspect because only gave 40.6 per cent or the competence of written language learning.

Table 1. Results of Regression Analysis of Indicators Competency of Written Language

\begin{tabular}{|c|c|c|c|c|}
\hline Independent Variables & B & $\begin{array}{c}\text { Standard } \\
\text { Error }\end{array}$ & $\mathbf{T}$ & Significant \\
\hline Constant & 42.868 & 4.783 & 8.962 & .000 \\
\hline \multicolumn{5}{|l|}{ The theory of written language skill } \\
\hline 1. The nature of reading & 1.363 & .210 & 6.490 & .000 \\
\hline 2. The nature of writing & 1.666 & .183 & 9.115 & .000 \\
\hline Language skills lea & 1.329 & .200 & .6 .651 & .000 \\
\hline Language skills & 1.674 & .140 & 11.916 & .000 \\
\hline Reading skill & 1.969 & .369 & 5.338 & .000 \\
\hline \multicolumn{5}{|c|}{ Dependent variable: competencies of Language skills subject } \\
\hline $\mathrm{R}$ Square $=.899$ & \multirow{2}{*}{\multicolumn{4}{|c|}{$\begin{array}{l}\mathrm{F}=328.417 \\
\text { Sig. }=.000\end{array}$}} \\
\hline Adjusted R Square $=.897$ & & & & \\
\hline Constant & 133.437 & 9.523 & 14.013 & .000 \\
\hline Seriousness in 1 & 5.770 & .413 & 13.979 & .000 \\
\hline Motivation in learning language & .089 & .060 & 1.480 & .000 \\
\hline \multicolumn{5}{|c|}{ Dependent variable: competencies of Language skills subject } \\
\hline $\mathrm{R}$ Square $=.410$ & & & \multirow{2}{*}{\multicolumn{2}{|c|}{$\begin{array}{l}\mathrm{F} \quad=104.093 \\
\text { Sig. }=.000\end{array}$}} \\
\hline Adjusted R Square $=.406$ & & & & \\
\hline Constant & 71.096 & 6.695 & 10.620 & .000 \\
\hline Writing skill & 2.058 & .238 & 8.661 & .000 \\
\hline Media utilizing & 2.445 & .578 & 4.321 & .000 \\
\hline Implementing written & 3.454 & .237 & 14.602 & .000 \\
\hline \multicolumn{5}{|l|}{ language learning skill } \\
\hline \multicolumn{5}{|c|}{ Dependent variable: competencies of Language skills subject } \\
\hline $\mathrm{R}$ Square $=.754$ & & & \multirow{2}{*}{\multicolumn{2}{|c|}{ Sig. $=.000$}} \\
\hline Adjusted R Square $=.752$ & & & & \\
\hline
\end{tabular}

Table 1 above presents the information of the indicators from three aspects. From the cognitive aspect, the nature of reading had more influence than the nature of wring. Furthermore, in the affective aspect, seriousness in language learning had greater influence than motivation on learning language. For psychomotor aspect, implementing written language learning skill had the biggest influence among other indicators. It can be concluded that all indicators had positive influence on written language learning.

Based on the research result showed that cognitive competence related to the competencies that should be mastered by teachers in written language learning were to learn the theory of language skills. The theory of language skills are the nature of listening, speaking, reading and 
writing. Overall respondents agreed that teachers require different competencies in written language learning. The results of this study have been supporting the previous research showed that to improve the quality of teachers in written language learning on Indonesian language subject required a variety of cognitive competencies [3, 14]. Language learning is seen as a recursive process that involves cognitive and metacognitive processes [15]. Language is considered as a window facing the world, increasing knowledge and intellectual production[16]. Cognitive competencies related to the knowledge of the language that requires a variety of strategies such as planning, monitoring understanding and evaluating knowledge.

Competency affective aspect describe the process of someone to recognize and adopt certain values and attitudes in written language learning that guide him in life. This is in line with the purpose of Indonesian education is that to educate the Indonesian that faithfulness and piousness and integrity. Written language learning may be used as a medium to build character education. Therefore, an elementary school teacher requires different competencies for excellent Indonesian language learning subject.

Overall, respondents agree that teachers require different competencies in written language learning. The competences are seriousness and motivation in learning written language. The results of this research have supported previous research which shows that to improve the quality of teachers in the written language learning needed affective competencies[17]. Affective domain in language learning are discipline, self-efficacy, tolerance, autonomy, willingness to take risks, motivation, and interest[18]. That skill associates with mental, social and personal skills[12]. Self confidence when language learning impact on natural activity to keep interest and motivation[19]. Students who feel anxious, reluctant to use the language, are afraid of making mistakes, are not comfortable using the language inside or outside the classroom, would defer the performance of students when learning languages[20].

Overall, respondents agreed that primary teachers need different competencies in written language learning. The competences are writing skill, media utilizing skill, implementing written language learning skill. The results of this research have supported previous research which shows that to improve the quality of teachers in written language learning required psychomotor competencies. This competence is closely related to students' cognitive and affective competencies[21]. In general, when learning the language, students gain knowledge and this knowledge will only turn into production through the "skill". sychomotor is a result of production that involves language creativity, generation of ideas and expressive values using language tools[21]. Language skills such as psychomotor competency can be demonstrated on communication activities and learning skills.

\section{Conclusion}

Written language learning competencies need to be mastered by the primary school teachers on Indonesian subject. These competencies need to be mastered by the teacher in elementary school on order the learning objectives can be achieved well. Therefore, the competences that required to be mastered by teacher in written language learning are cognitive, affective, and psychomotor competences.

\section{Acknowledgment}


Thank you to Universitas Negeri Padang for permitting this research.

\section{References}

[1] A S Chaudhry and A Al-Adwani 2019 English Language Teaching 125

[2] E Ç Özdemir and H Akyol 2019 Universal Journal of Educational Research 7563

[3] C Wu et al 2019 ACS Sustainable Chemistry \& Engineering 72169

[4] E T Yaghi, A Abdullah and Z Mustafa 2019 Turkish Online Journal of Educational Technology-TOJET 1840

[5] Walczyk J J and Griffith-Ross D A 2007 The Reading Teacher 60560

[6] M. Grünke 2019 International Electronic Journal of Elementary Education 11291

[7] E Sukma 2007 Diksi 141

[8] D Ardiansyah and Y Suryana PEDADIDAKTIKA: Jurnal Ilmiah Pendidikan Guru Sekolah Dasar 543

[9] E Önen and M K T Yayvak 2019 Journal of Education and Training Studies 735

[10] F Kamali and H Noori 2015 Cumhuriyet Üniversitesi Fen-Edebiyat Fakültesi Fen Bilimleri Dergisi 36948

[11] N Rahimi and R Karimzadeh 2011 Applied Catalysis A: General 39816

[12] M Mansouri, A Al-Khazraji, S Yin Teh, M F Harkat, H Nounou, and M Nounou 2019, The Canadian Journal of Chemical Engineering 97860

[13] J W Creswell, A C Klassen, V L Plano Clark and K C Smith 2013 Bethesda (Maryland): National Institutes of Health 2013543

[14] J Pendlebury et al 2015 Physical Review 920920003

[15] Kirkland M R and Saunders M A P 1991 Tesol Quarterly 25105

[16] M K M Muflih 2019 International Education Studies 12135

[17] E Sukma, R Ritawati, R Rahmatina and A Suriani 2018 International Conference on Language, Literature, and Education (ICLLE 2018) Vol 263 (Indonesia/Atlantis Press) p. 58

[18] Ş Tok and A Kandemir 2015 Procedia-Social and Behavioral Sciences 1741635

[19] P Demirel, Q C Li, F Rentocchini and J P Tamvada 2019 Small Business Economics 52759

[20] E Sukma, R Mahyudin, R Rahmatina and A Suriani 2019 Seventh International Conference on Languages and Arts (ICLA 2018) vol 301 (Indonesia/Atlantis Press) p . 379

[21] E A E Elnadeef and A H E H Abdala 2019 Online Submission 2230 